\title{
SUSTAINABILITY ASSESSMENT FOR CORPORATE MANAGEMENT OF ENERGY PRODUCTION AND SUPPLY COMPANIES FOR LITHUANIA
}

\author{
Žaneta STASIŠKIENE ${ }^{1}$ and Jūratè ŠLIOGERIENE் 2 凶 \\ 1 Institute of Environmental Engineering, Kaunas University of Technology, \\ K. Donelaičio str. 20, LT-44239 Kaunas, Lithuania \\ E-mail: zastas@ktu.lt \\ ${ }^{2}$ Department of Construction Economics and Property Management, Vilnius Gediminas \\ Technical University, Sauletekio al. 11, LT-10223 Vilnius, Lithuania \\ E-mail: jurate.sliogeriene@lpc.lt
}

Received 8 October 2008; accepted 19 December 2008

\begin{abstract}
Corporate responsibility has become an important issue for management to address. The responsibility of the organization for the public environment (ecological, social and economic aspects of the environment) has become a matter of management attention referring to the entire organization and all major stakeholders. Therefore safe, environmentally sound, and economically viable energy production and supply should be essential part of management issues. The anticipated closure of the Ignalina Nuclear Power Plant at 2009 will change the situation of electricity generation in Lithuania significantly. The costs of electricity generation and distribution are the most important criteria shaping decisions in the energy production and supply companies. Sound energy and environmental accounting must be the basis of any strategic decision making in order to keep up with the increasing complexity of energy and environmental problems. Efficiency, equity, ecological integrity, and technological change are introduced as fundamental aspects that need to be considered in a comprehensive sustainable energy production and supply framework. Since these issues cannot be suitably included within the frame of a single model, a combination of ecological, economic, technological and social measures for different aspects of Lithuanian energy system and sustainable development are analysed.
\end{abstract}

KEYWORDS: Asset; Sustainability assessment; Environmental accounting; Engineering infrastructure; Valuation methods

\section{ENERGY INFRASTRUCTURE DEVELOPMENT TASKS}

The economy of any country may be evaluated according to the development level of its energy infrastructure. Economic development is directly related with infrastructure adapted to industrial development possibilities and supply of energy resources. Therefore, the growing price of energy resources and expensive infra- structure is becoming the key issue while solving questions of economic development and integration; and this factor may turn into the one that influences the speed of economic growth of the country the most. Attention of the society to energy sector development is related to the need of welfare growth as well as the aspiration to have safe and ecologically harmonised environment (Staniškis et al., 2005). 
The activity of electricity production, transmission and distribution assures the supply of energy resources and thus creates the ground for welfare of the society. However, the side effect of this activity is the rapid use of nonrenewable resources and negative impact on the surrounding environment. Operating power plants that use organic fuel emit $\mathrm{SO}_{2}$, $\mathrm{NO}_{\mathrm{x}}, \mathrm{NH}_{3}$ as side combustion products and other hazardous particles to the environment, high-tension transmission networks cause an increased electromagnetic radiation (Staniškis et al., 2004). These factors harm the biological variety of environment, human health and activity products of people, i.e., the quality of agriculture products, buildings, construction materials, etc.

While performing its activity and estimating energy production or transmission costs, an electricity producer estimates costs related to environment protection. Environment protection costs encompass all ecology measures applied by the company: from expenses to the evaluation of particular work places from the health protection point of view, equipment and devices that reduce harmful effect, purchase of more ecological fuel and more effective technologies, property operation and amortisation deductions that enable to accumulate funds for the upgrade of technologies to taxes for the use of natural resources and pollution permits. However, such applied measures are not sufficient to fully regard the effect made on the environmental system. There exist environmental protection costs that are not related to direct production costs incurred by the company, such costs are "external", even though due to this specific activity the society also incurs expenses, which are "relegated" to the health care system or groups of inhabitants that experience losses due to low-quality agricultural products and additional property operational costs. Thermal power stations that use organic fuel - coal, fuel oil, gas - make the greatest impact on the environment in the electricity sector (Staniškis et al., 2005).
It is stated in the report on energy resources announced by the World Energy Council in 2001 that "there are sufficient resources in every region of the world that would satisfy the growing energy demand even in the $21^{\text {st }}$ century; however, there are no new special technologies that would markedly reduce the part of organic fuel in the general energy balance in the nearest future" (World Energy Council, 2001). This is why sustainable development of the energy system and efforts to combine rational production limiting down the use of resources, maximal efficiency and reduction of negative impact on the environment are becoming significant task. It is known that fuel costs form slightly more than one third of costs in the structure of energy production costs at thermal power stations. The remaining part of costs is capital and management costs. In wind and hydro power plants, the capital and management costs form up to 95 percent of all costs (see Figure 1) (Juozaitis, 2007). Therefore, it is important to apply effective property management methods of energy infrastructure, such as quantity optimize, resource control and property accounting.

According to the 2001/77/EC Directive of the European Union Parliament and Council as of July 27, 2001, member states should endeavour that the part of renewable energy would make more than $12 \%$ in the general energy balance and $22.1 \%$ in the electricity balance of the country including hydro power plants in year 2010. In the National Energy Strategy, Lithuania confirms its obligations to the European Union regarding the implementation of greater use of renewable energy resources for electricity generation. After constructing wind power plants and thermal power stations using biomass fuel, the part of renewable resources in the general electricity production balance will make about $7 \%$ by year 2010. At the moment energy production from renewable resources, including hydro energy, amounts to $4 \%$. 


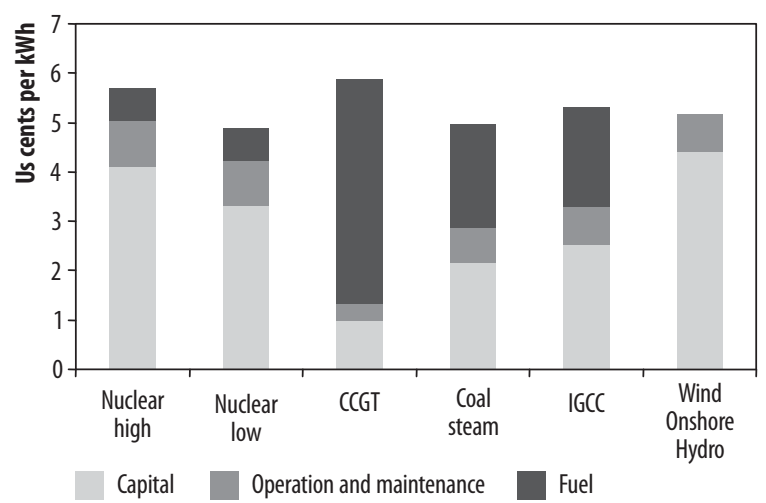

Figure 1. Power generation costs, US cent/kWh (Juozaitis, 2007)

As the economy of Lithuania is growing and the demand for electricity is increasing, the planned decommissioning of Ignalina Nuclear Power Plant in 2009 will have an essential impact on the supply of reliable electric power. Table 1 presents the forecasts of capacities and capacity balances present in Lithuanian power plants (prepared according to the methodology of the European Transmission System Operators Association).

Presently up to $80 \%$ of electricity necessary for the needs of Lithuania is generated at Ignalina NPP. Nuclear power uses relatively small amounts of nuclear fuel in the generation process, its transportation is not complicated, its impact on the environment is not big, very small amounts of hazardous substances

Table 1. Forecast of capacities of Lithuanian power plants, MW

\begin{tabular}{llll}
\hline & 2006 & 2010 & 2015 \\
\hline Ignalina NPP & 1300 & - & - \\
$\begin{array}{l}\text { Thermal power stations } \\
\text { Hydro power plants }\end{array}$ & 2330 & 2380 & 2460 \\
$\begin{array}{l}\text { Renewable energy } \\
\text { resources }\end{array}$ & 40 & 220 & 340 \\
$\begin{array}{l}\text { Total capacity } \\
\begin{array}{l}\text { Capacity without wind } \\
\text { and hydro power plants }\end{array}\end{array}$ & 3640 & 2400 & 2500 \\
\hline
\end{tabular}

and substances causing "heat effect" are emitted to the environment.

The use possibilities of the majority of renewable energy resources potential are limited; therefore, the use of renewable energy resources will form an essential technological part in the world energy balance only after 3040 years (World Energy Council, 2001). Thus, it would not be possible to secure satisfaction of the society needs without the created, operating and regularly upgraded and modernised production, transmission and distribution infrastructure. The surging price of energy resources and its generation will encourage to consider all possibilities of reducing production costs by implementing technologies saving resources, by assessing the necessity of ecological measures and by applying rational management methods. As new requirements for infrastructure management are set and attempts are made to control and reduce its impact on the environment, it is necessary to use for valid methods of infrastructure property management, assessment and analysis (Staniskis and Stasiskiene, 2006).

\section{FEATURES OF ENERGY INFRASTRUCTURE}

Solving issues of balanced development and operation, accepting management solutions, it is important to assess the production, transmission and distribution costs that would cover both - direct internal costs and external environmental impact assessment costs.

The level of internal production, transmission and distribution costs directly depends on the value of property used for activity, incurred operational costs, amortisation deductions. Therefore, the accounting of assessed correct property value in companies' accounting documents is one of the more important indexes while calculating the production, transmission and distribution costs. This is also required by International Accounting Standards regulating companies' property accounting. 
The electricity system of Lithuania unites energy producers which use diverse energy resources for production: nuclear power, organic fuel (gas, fuel oil, oremulsion), renewable energy resources (water, wind, geothermal energy) and suppliers engaged in electric energy transmission and distribution.

The infrastructure of energy sector - property for energy production, transmission and distribution - forms a very significant part in the economy of every country. The biggest part of property of energy infrastructure companies is special-purpose property: technological lines, devices, equipment, pipelines, cable and overhead power transmission and distribution lines, transformer substations and switchyards, hydro-technical constructions and installations, wind power plant equipment, etc. Property of the energy sector, constructions and equipment, serve for a long period of time - from several to several dozens of years; technological changes are slow, renewal requires extremely large investments and the payback time is long. Therefore, combining operational measures, new technologies function in the common system along with effectively serving property and conservative technologies, which do not save resources and which are often electrotechnical property items created in a non-rational way (Schenler, 1999).

Infrastructure is a limiting element in the energy sector, and it influences the operation of the entire energy system the most. Gradual modernisation of the system, replacement of technologies by more reliable, rational and environmentally-friendly ones, rational property management decisions and suitable accounting of property are the features of a contemporary company of energy infrastructure. Implementing these measures, it is also equally important to establish suitable depreciation norms that would enable to accumulate funds for property renewal. The property of energy infrastructure wears technologically the most rapidly, while the period of physical operation of a property item may be much longer. Amortisation deductions of a property item are accounted as internal costs of a company; still, they create positive cash flows. It is also important that the property depreciation would be calculated from the correctly established value of a property item. Depreciation deductions from property that has not been assessed suitably will not result in sufficient funds necessary for the property renewal. Meanwhile, overvalued property will increase the level of company costs, will have negative impact on profitability and other activity indexes. This is why the correct establishment of value of infrastructure property is significant in the property accounting and management processes (Šliogerienè, 2008).

\section{ASSESSMENT OF ENERGY COMPANIES' ENVIRONMENTAL IMPACT - EXTERNAL COSTS}

The impact of various industrial activities on external environment is being analysed from the middle of the last century already after attention was paid to evidently negative after-effects of activity on the quality of human life and environment. External costs appear when certain social and economic activity affects the part of the society which is not related with this activity and when this impact and caused consequences are not compensated. Following the Fifth Environment Action Programme "Towards Sustainability", the European Union member states are searching for solutions and methods that would enable the integration of environmental parameters into economic activity indexes of companies assuring that the factor of environmental protection would be counted in while setting production costs and the correct price (European Communities, 2004). While the environmental impact made by a number of industrial sectors (especially chemistry, cellulose, etc.) has been studied more extensively, impact monitoring 
is performed, economic sanctions are applied, activity is regulated by the law and normative acts, few studies have been performed on the external impact of energy companies yet.

In the electric power field, external costs appear due to combustion products emitted by power plants to the environment $-\mathrm{SO}_{2}, \mathrm{CO}_{2}$, $\mathrm{NO}_{\mathrm{x}}$ as well as other hazardous particles, which harm human health, biological variety, quality of agricultural production, construction materials. Electromagnetic radiation caused by high-tension electricity installations affects the quality of life of people who live or work near such objects. Usually an electricity producer does not take into account the impact made on real estate, agriculture or health of people living around energy objects. In this case environmental protection costs are "external", even though society members incur actual costs due to decisions accepted by electricity producers.

Electric power production, transmission and distribution costs are considered to be the most important criteria while accepting strategic and management decisions in the energy system. All direct activity costs are computed in them, including the property depreciation costs calculated from the actual property value. While companies are already making efforts that the cost of property replacement would reflect actual investments that comply with ecological requirements, the impact of atmosphere pollution and climate change on the environment and human health caused by the electric power production process should be assessed respectively too (European Communities, 2004). This impact has to cover the entire cycle from production to distribution rather than only the operation of power plants.

The power generation process covers separate cycles from production to supply to the user and systems that combine complicated technologies; therefore, in order to compare different kinds of damage caused by them, the transformation of a specific kind of dam- age into a monetary unit is made. ExternE methodology is considered the most suitable for damage calculated in the power sector - it is used to assess impacts by separate kinds of damage, the majority of which depend on the location of a power plant. After performing such assessment, damage costs are calculated, and external costs form the bigger part of them. After summing up internal and external costs, social costs are received (Hohmeyer, 1988). For example, social costs incurred in companies that use renewable energy technologies for energy generation (wind, water, biomass) may be equal or even lower than the social costs of companies using regular organic fuel technologies despite the fact that advanced technologies are often expensive and predetermine high internal costs.

Solving these tasks, the European Union (within the implemented $6^{\text {th }}$ Framework Programme) funded the project of sustainable energy systems CASES (European Communities, 2006). The aim of the project was to assess external and internal energy production costs in the European Union member states and to present reliable and grounded variants of electric power system development, when external costs are integrated into the entire chain of electric power supply system. During the project implementation, external energy generation costs of the Baltic States were assessed as well.

In Lithuania the calculation of external energy generation costs applying ExternE methodology was performed by Štreimikienè and Pušinaitè (2008), and the impact of external energy generation costs on the functioning and sustained development of Lithuanian energy systems was evaluated by Norvaiša and Galinis (2004). Calculations made by these authors have been quoted in this article.

Seven kinds of damage were evaluated according to ExternE methodology, the main being impact on human health, crop, residential environment and buildings. It was taken into consideration that some kinds of pollutants af- 
fected not only the environment near energy objects but were carried away by rushes of wind and caused considerable damage many kilometres away from the source. EcoSense software is used for making calculations. EcoSence encompasses combined models of air quality and impact assessment and a data base with entered initial data of all EU countries related thereto.

On the basis of results of the implemented CASES project (European Communities, 2006), the means of external costs (due to classic air pollutants) have been calculated for 27 European Union member states in order to show typical and average conditions. While making the calculations, the emission results of the following pollutants have been received: $\mathrm{NH}_{3}$; NMVOC; $\mathrm{NO}_{\mathrm{X}}$; PPMcoars; - $\mathrm{PPM}_{25}$ and $\mathrm{SO}_{2}$. Assessing the impact on human health, fertility, damage to materials, "losses of biological variety", the territory of researched objects' location covered the entire Europe. The aim of the programme is the possibility to integrate external costs into power generation costs.

According to reports of Lithuanian power plants on the emission amounts of classic pollutants from the main power generation sources furnished to the Ministry of Environment of Lithuania and according to assessments of damage costs performed using ExternE methodology, the calculation results of average external power generation costs in Lithuania are presented in Table 2 (Štreimikienè and Pušinaitè, 2008).
The average power generation costs made 1.4 LTLcnt/kWh or 0.4 EURcnt/kWh per kilowatt-hour in Lithuania in 2005. The highest external costs were registered in thermal power stations burning fuel oil, and the lowest - in power plants burning natural gas. The lowest external power generation costs are incurred by Ignalina NPP as the nuclear power plant emits a very small amount of pollutants to the atmosphere. With Ignalina NPP operating, the external power generation costs were low in Lithuania in 2007 as well, despite the fact that Ignalina NPP generated slightly less electricity and the share of production of power plants using organic fuel increased. Nonetheless, the decommissioning of Ignalina NPP will make a big impact on the surge of average external power generation costs in Lithuania in 2009 (Šliogerienè, 2008).

Lithuanian power plants are paying pollution taxes for emissions to the atmosphere. Still, these taxes are very small as compared with external costs. The increase of pollution taxes would influence the costs structure of energy sector companies. Specifically from 2009, when Lithuania will no longer have the cheap energy source - Ignalina Nuclear Power Plant.

Therefore, companies of electric power sector should prepare already now to take into account ecological requirements growing more stringent, pollution taxes, which will be increased in future, and integration of external costs into the company activity costs, while accepting decisions regarding the establishment

Table 2. External power generation costs in Lithuania in 2005, thousand EUR

\begin{tabular}{llll}
\hline & $\begin{array}{l}\text { Power plants (without } \\
\text { wind, hydro, biomass fuel) }\end{array}$ & Ignalina NPP & $\begin{array}{l}\text { Total external costs } \\
\text { in the energy system }\end{array}$ \\
\hline $\begin{array}{l}\text { External costs, thousand EUR } \\
\text { Generation of power production, }\end{array}$ & 59697.2 & 59.3 & 59756.5 \\
MGWh & 3624 & 10338 & 14784 \\
External costs, EURcnt/kWh & 2.00 & 0.001 & 0.4 \\
External costs, LTLcnt/kWh & 6.90 & 0.003 & 1.40 \\
\hline
\end{tabular}


of production prices, creation of new generation sources, investments and implementation of development programmes. It is necessary to apply property accounting measures recognised on the international level in daily activity decisions when performing the activity analysis, assessing cash flows and managing the accounting of infrastructure property, to follow value changes of infrastructure property, to define actual depreciation costs that would comply with contemporary technological and ecological requirements accordingly, and to plan regular expenses in the costs structure for reducing the activity impact on the environment.

\section{SUSTAINABILITY ASSESSMENT IN ENERGY PRODUCTION AND SUPPLY COMPANIES}

Corporate sustainability is a business approach that aims to create long-term shareholder value by embracing opportunities and managing risks deriving from economic, environmental and social developments. During the assessment those performances of energy production and supply companies were analysed using the special set of criteria and weightings (Dalal-Clayton and Sadler, 2004), with are presented in Table 3.

Table 3. Corporate sustainability assessment criteria and weightings (Dalal-Clayton and Sadler, 2004)

\begin{tabular}{lll}
\hline Dimension & Criteria & Weighting, \% \\
\hline Economic & Codes of conduct/compliance/corruption & 3 \\
& Corporate governance & 5.4 \\
& Customer relationship management & 3 \\
& Financial robustness & 3.6 \\
& Investor relations & 2.4 \\
Risk \& crisis management & 3.6 \\
Scorecards/measurement systems & 4.2 \\
& Strategic planning & 5.4 \\
& Industry specific criteria & 5 \\
& Environmental policy/management & \\
Environmental performance & 3 \\
Environmental reporting & 4.2 \\
& Industry specific criteria & 1.8 \\
& Corporate citizenship/philanthropy & 4 \\
Stakeholders engagement & 2.4 \\
& Labour practice indicators & 4.2 \\
& Human capital development & 3 \\
& Knowledge management/organisational learning & 3 \\
Social reporting & 1.8 \\
Talent attraction \& retention & Standards for suppliers & 2.4 \\
& Industry specific criteria & 1.8 \\
\hline
\end{tabular}


The major source for the information was Sustainable asset management (SAM) questionnaire, which was completed by companies (Werther and Chandler, 2006). Further sources include company and third-party documents as well as personal contacts between the analysts and companies. Various company documents were analysed including:

- environmental reports;

- health and safety reports;

- annual financial reports;

- all other sources of company information (internal documentation, brochures and websites).

Analyst also reviewed media, press releases, articles and stakeholder commentary written about the companies over past year. The assessment was conducted in three stages, with are presented in Table 4 (Dalal-Clayton and Sadler, 2004).

From our experience it can be stated that the more accurately the issues of acceptability and constraints are prior-researched and scoped the more relevant and justifiable results can be got.

Sustainability assessment was performed in light of international sustainability assessment practice for the purpose of highlighting the further opportunities available to Lithuanian energy production and supply companies to develop and implement a corporate sustainability strategy. It is suggested that sustainability assessment should ultimately be inte- grated with planning and decision-making at many levels across the companies, and that the benefits of sustainability assessment in terms of delivering sustainable outcomes is likely to be even greater at more strategic levels of decision-making.

Sustainability assessment is a general term that encompasses a range of processes that broadly aim to integrate sustainability concepts into decision-making. Across the many different forms of sustainability assessment now being applied in a wide range of decisionmaking contexts around the world, a simple distinction can be drawn between "external" sustainability assessments that may be conducted by regulators as part of a project approvals process, and "internal" sustainability assessment conducted by companies themselves as part of their business planning and decision- making processes (Pope and Grace, 2006).

The sustainability assessment process in energy production and supply companies was conducted voluntary for the purpose of assuring of improvement decisions compatibility with sustainability principles. It is suggested that experience gained from this process will prove invaluable in development of sustainability initiatives, since internal sustainability assessment that guides key business planning and decision-making processes is an important and powerful component of a corporate sustainability strategy (Gheorghe, 1999).

Table 4. Stages of sustainability assessment

Weighting of answers Weighting of answers (if signed by senior (if not signed) management)

\begin{tabular}{lll}
\hline Stage 1. Questionnaire assessment & $70 \%$ & $50 \%$ \\
Stage 2. Quality and public availability of information & $20 \%$ & $33.4 \%$ \\
$\begin{array}{l}\text { Stage 3. Verification } \\
\quad \text { truthfulness of questionnaire }\end{array}$ & $10 \%$ & $16.6 \%$ \\
$\quad$ review of a company's involvement of critical issues & & \\
\hline Final score & $100 \%$ & $100 \%$ \\
\hline
\end{tabular}


For efficient assessment process and optimal use of the results interpretation or operationalisation of sustainability concept in a way that is meaningful to the decision at hand is required (Pope et al., 2004). Therefore operationalisation for decision-making requires the identification of sustainability criteria. These criteria should reflect both accepted high-level sustainability principles, for example those included in Lithuanian sustainable industrial development strategy, and the issues pertaining specifically to the analysed company. It has been observed that reconciliation of the two is often difficult and linkages are not always evident.

Despite the challenges and difficulties, the invocation of the overarching principles is an important reminder of the "bigger picture" of sustainability beyond the decision at hand, and the essentially integrated nature of the concept. In practice, however, the sustainability criteria identified as being relevant to relatively low-level decisions and often quickly fall into separate environmental, social and economic or technical categories and thus sustainability assessment may also be called "triple bottom line" assessment. Seeking to avoid this for each criteria identified, best practice sustainability assessment seeks to:

- minimise negative impacts;

- maximise positive outcomes; and

- ensure that relevant acceptability criteria are met.

It is important to note that despite the lot of the issues discussed above, the acceptability and constraints analysis is a very important part of the overall process because it provides means by which sustainability can be achieved.

The sustainability assessment performed in the companies was successfully integrated planning process and stakeholder engagement. Some suggestions have been made as how future processes could be streamlined and improved, particularly in relation to constraints analysis. In particular it was recommended that:
- acceptability limits be identified early in the process as far as possible, enabling certain areas to be categorically ruled out of consideration;

- the relationship between constraints analysis and impact analysis be more clearly defined, recognising that some issues could be dealt with at the at the constraints stage and therefore be legitimately omitted from the impact analysis.

It should be stressed that standartisation of results for reporting purposes offers several benefits, including enhanced transparency, comparability between companies and the opportunity to continue self-regulation development, but may reduce differentiation between companies. Also for the purpose of contributing to the management of sustainable development issues, may lead to important company-specific issues being ignored. Therefore credible, transparent and comparable reporting methodologies would contribute to the development of a robust and effective framework within which the companies would self regulate (based on performance). However there is a risk that the development of industry-wide standards might have impacts on innovation and competitive advantage within the sector, and implement by default a "command-and-control" approach despite the ability to self-regulate according their sustainability performance. Therefore the further work is foreseen in this area.

\section{CONCLUSIONS}

1. After sustainability analysis the need to balance economic, social and environment issues in decision-making was clearly recognised by energy production and supply companies in Lithuania: sustainable decision-making gave them the tools to assess the sustainability of their plans and decisions. A key element to this is measuring the effectiveness of sustainable development policies. Tools for measuring sustainable development provides examples of how organisations are achieving this. 
2. One of effective ways to encourage the use of renewable energy resources and to ground development, renovation and reconstruction projects is the replenishment of economic analysis of projects by the constituent of external energy generation costs.

3. The assessment of power generation costs in power plants using renewable energy resources (hydro and wind) in Lithuania applying ExternE values has shown that these technologies are exceptional by external energy generation costs that are from ten to several hundred times lower than those of power plants burning organic fuel; thus, assessing the value of energy sector companies by economic methods (discounted cash flow, income capitalization), it would be necessary to assess not only the direct incurred costs of companies but also all incurred activity social costs.

4. The results will be used for further investigations on practical implications of sustainability concept in management accounting systems. The development, implementation and evaluation of the management accounting systems will be used to further elaborate the process of integrating sustainable criteria in decision-making. Both developments in the concept of sustainable development and management accounting can significantly contribute to this process.

\section{REFERENCES}

Dalal-Clayton, B. and Sadler, B. (2004) Sustainability Appraisal - A Review of International Experience and Practice. International Institute for Environment and Development.

European Communities (2004) Work Package 6: Revision of External Cost Estimates. New Elements for the Assessment of External Costs from Energy Technologies (NEWEXT). Final Report. FP5 Project. Contract No. ENG1CT-2000-00129.

European Communities (2006) Cost assessment for sustainable energy systems (CASES). FP6 Project. Action Line: SUSTDEV-1.2.8 Socio- economic tools and concepts for energy strategy. Project Reference: 518294.

European Transmission System Operators Association (2008). Available at: http://www.etso-net. org/

Gheorghe, A.V. (1999) Integration and decision support systems for energy policy management and comparative assessment studies, International Journal of Global Energy Issues, 12(1/2/3/4/5/6), pp. 33-59.

Hohmeyer, O. (1988) Social Costs of Energy Consumption. Berlin: Springer Verlag.

Juozaitis, R. (2007) A new nuclear power plant in Lithuania and new interconnections. In Proceedings of the $2^{\text {nd }}$ International Conference on Electric and Management Technology, Kaunas, Lithuania, 3-4 May 2007.

Norvaiša, E. and Galinis, A. (2004) Išorinių energijos gamybos kaštu itaka Lietuvos energetikos sistemos funkcionavimui ir darniai pletrai [Impact of external energy generation costs on functioning and sustainable development of the Lithuanian energy system], Energetika, No. 2, pp. 1-8. (In Lithuanian)

Pope, J. and Grace, W. (2006) Sustainability assessment in context: Issues of process, policy and governance, Journal of Environmental Assessment Policy and Management, 8(3), pp. 373-398.

Pope, J. Annandale, D. and Morrison-Sounders, A. (2004) Conceptualising sustainability assessment, Environmental Impact Assessment Review, 24(6), pp. 595-616.

Schenler, W.W. (1999) Full value costs for sustainable electric utility options, International Journal of Global Energy Issues, 12(1/2/3/4/5/6), pp. 208-217.

Staniskis, J.K. and Stasiskiene, Z. (2006) Environmental management accounting in Lithuania: exploratory study of current practices, opportunities and strategic intents, Journal of Cleaner Production, 14(14), pp. 1252-1261.

Staniškis, J.K., Stasiškiene, Ž. and Jasch, Ch. (2005) Assessment of Environmental Costs for Sustainable Industrial Development. Monography. Kaunas: Technologija.

Staniškis, J.K., Stasiškienè, Ž. and Kliopova, I. (2004) Subalansuotos pramonés pletros strategija: teorija ir praktika. Monografija [Sustainable Industrial Development: Theory and Practice. Monography]. Kaunas: Technologija. (In Lithuanian) 
Šliogerienè, J. (2008) Property valuation in enterprises: Fair value and sustainability issues, Environment Research, Engineering and Management, No. 2(44), pp. 57-68.

Štreimikienè, D. and Pušinaitè, R. (2008) External cost of electricity generation in Lithuania, Environment Research, Engineering and Management, No. 2(44), pp. 34-40.
Werther, W.B. and Chandler, D. (2006) Strategic Corporate Social Responsibility: Stakeholders in a Global Environment. Sage Publications, Inc.

World Energy Council (2001) Energy Markets: The Challenges of the New Millennium. Energy for People, Energy for Peace. Conclusions and Recommendations. 18 $8^{\text {th }}$ World Energy Congress, Buenos Aires, Argentina, 21-25 October, 2001.

\section{SANTRAUKA}

\section{DARNIOS APLINKOS IVERTINIMAS VALDANT LIETUVOS ENERGIJOS GAMYBOS IR TIEKIMO İMONES}

\section{Žaneta STASIŠKIENĖ, Jūratė ŠLIOGERIENE்}

İmonių atsakomybė už aplinką (socialiniu, ekologiniu, ekonominiu aspektu) yra vienas svarbiausių klausimu nustatant imoniu veiklos prioritetus ir priimant veiklos sprendimus. Svarbiausias šiandienos energetikos uždavinys - patikima saugios, ekologiškai švarios, efektyvios ir ekonomiškai patrauklios energijos gavyba. Š tiksla igyvendinti ịmanoma tinkamai formuojant energetikos ūkio valdymo politika, keičiant ir nustatant valdymo, naudojimo išlaidas, įvertinant energetikos infrastruktūros poveikị ekologijai. Svarbiausias veiksnys, lemiantis pasirenkamus sprendimus elektros energijos gamybos ir paskirstymo sektoriuje, yra energijos gamybos ir paskirstymo kaina. Gamybos ir paskirstymo kainu lygiui įtaką daro turto struktūra, ì kainą integruoti aplinkos taršos bei išorinių taršo sąnaudų mokesčiai. Tačiau po 2009 m., uždarius Ignalinos atominę elektrinę, situacija Lietuvos elektros energetikos sektoriuje pasikeis iš esmès, nes pasikeis energijos gamybos šaltiniai. Siekiant sudaryti aplinkai visapusiškai saugią elektros energijos gamybos ir perdavimo struktūra, efektyvumas, ekologinis integruotumas, technologinis inovatyvumas yra tie pagrindiniai kriterijai, kuriuos būtina vertinti rengiant sprendimus. Elektros energetikos sektoriuje veiksmingas gali būti tik toks valdymo modelis, kuris suderins ekologinius, socialinius, technologinius aspektus su darnios aplinkos analize. 